<総 説 $>$

（受理: 平成 25 年 3 月 29 日）

\title{
ボンド磁石の磁粉の分散と磁石のエネルギー分野への応用 Dispersion of Magnet Powder of Bonded Magnets and Application of Magnets to Energy Field
}

\section{1.はじめに}

ボンド磁石 (Polymer bonded magnet) は, ポリマー (バインダー) に酸化鉄系フェライトや希土類系磁石粉末 （磁粉）を高濃度に混練・分散させた磁性コンパウンドを 成形加工して得られる。今日工業的に使用されている永久 磁石は, 鋳造磁石, 燒結磁石, ボンド磁石に分類される。

ボンド磁石は, 鋳造磁石や焼結磁石に比べて非磁性であ るバインダーの容量分だけ磁気特性が劣る。しかしながら ボンド磁石は, 複雑形状, 寸法精度, 薄肉化, 割れ・欠け にくさ，金属との一体化成形，フレキシブルで長尺広幅磁 石が得られる，量産性に優れるなど，工業材料として優れ た長所を有していることから, 電子・電気機器の小型化, 高性能化に不可欠なものとして広くに使用されている。

磁粉の分散は，ボンド磁石の磁気特性や機械的特性を高 め, 品質の安定化に極めて重要である。永久磁石のエネル ギー分野への応用では, モータや発電機の小型化・省エネ・ 効率化に有効に働き，今後ますます重要になる。

\section{2. ボンド磁石の概要}

\section{1 磁石粉末 (磁粉)}

表 1 にボンド磁石に使用されている磁粉の種類と平均粒 子径, 密度を示す。平均粒子経は, 分散性や充填量に関連 する他, 約 $10 \mu \mathrm{m}$ 以下の微細な希土類系磁粉では, 高温 加工や静電気による発火に関連するため重要な粉体特性で ある。例えば, ネオジム系 $(\mathrm{Nd}-\mathrm{Fe}-\mathrm{B})$ 磁粉の粒子径が

\footnotetext{
*日本ボンド磁性材料協会

東京都荒川区東日暮里 5-52-2 テ 116-0014

(神谷ビル 6F602 号)

The Japan Association of Bonded Magnetic Materials (JABM) Kamiya BLDG 6F-602, 5-52-2, Higashinippori, Arakawaku, Tokyo 116-0014, Japan
}

大きめで販売されているのは, 取扱い時の発火を防止する ためである。また, 磁粉には, 高い磁気特性の他, 高充填 性と混練性, さらに分散性や耐熱性などの特性が要求され る。粉体特性の圧縮密度は, ボンド磁石への磁粉の充填量 に関連し，圧縮密度が高いほど充填量も高くできる。

ボンド磁石の磁気特性は, 磁粉の種類と充填量で大部分 が決まるため, 応用製品の要求特性に適した磁粉を選定し 濃度を決めている。フェライトは, 磁気特性が高くはない がコストパフォーマンスに優れ, 複写機やプリンターの磁 気ロールなど大物部品に多量に使用されている。高い磁気 特性を発現するネオジム系等方性磁粉は, コンピューター のハードディスクドライブ (HDD) や光ディスクドラィブ (ODD) などの小型で高出力のモータに多量に使用されて いる。ネオジム系磁粉の製法は, 米国 GM 社が開発した 液体急冷法による薄帯を粉砕して得られる。 $\mathrm{Sm}-\mathrm{Fe}-\mathrm{N}$ 系磁粉は, $\mathrm{Sm}-\mathrm{Fe}$ 合金粉末を窒化して得られ, 平均粒子 経 $4 \mu \mathrm{m}$ 程度で表面処理し，取扱い時の安全性を高めてい

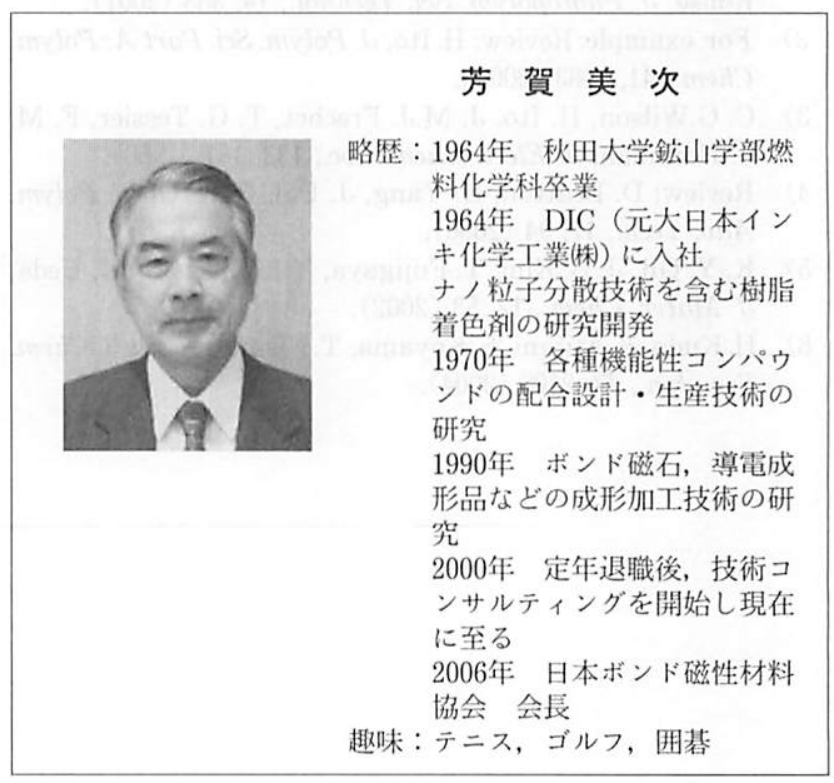


表 1 磁石粉末の種類之平均粒子径, 密度

\begin{tabular}{|c|c|c|c|}
\hline 種 類 & 組 & $\begin{array}{c}\text { 平均粒子径 } \\
(\mu \mathrm{m})\end{array}$ & $\begin{array}{l}\text { 密度 } \\
\left(\mathrm{g} / \mathrm{cm}^{3}\right)\end{array}$ \\
\hline \multirow[t]{2}{*}{ フェライト系 } & バリウムフェライト $\left(\mathrm{Ba} 0 \cdot 6 \mathrm{Fe}_{2} \mathrm{O}_{3}\right)$ & $1.0 \sim 1.3$ & 4.9 \\
\hline & ストロンチウムフェライト $\left(\mathrm{Sr} 0.6 \mathrm{Fe}_{2} \mathrm{O}_{3}\right)$ & $1.0 \sim 1.7$ & 5.0 \\
\hline $\begin{array}{l}\text { ネオジム・鉄 } \\
\text { ・ボロン系 }\end{array}$ & $\begin{array}{l}\mathrm{Nd}-\mathrm{Fe}-\mathrm{B} \text { 系 } \\
\left(\mathrm{Nd}_{2} \mathrm{Fe}_{14} \mathrm{~B}\right)\end{array}$ & $\begin{array}{l}\text { 厚さ: } 30 \\
\text { 長さ: } 150\end{array}$ & 7.6 \\
\hline \multirow{2}{*}{$\begin{array}{l}\text { サマリウム－ } \\
\text { コバルト系 }\end{array}$} & $1-5$ 型 $\left(\mathrm{SmCo}_{5}\right)$ & $5 \sim 10$ & 8.3 \\
\hline & $2-17$ 型 $\left(\mathrm{Sm}_{2}\left(\mathrm{Co}_{0.7} \mathrm{Fe}_{0.3}\right)_{17}\right)$ & $20 \sim 50$ & 8.5 \\
\hline $\begin{array}{l}\text { サマリウム・ } \\
\text { 鉄・窒素系 }\end{array}$ & $\begin{array}{l}\mathrm{Sm}-\mathrm{Fe}-\mathrm{N} \text { 系 } \\
\left(\mathrm{Sm}_{2} \mathrm{Fe}_{17} \mathrm{~N}_{3}\right)\end{array}$ & $2 \sim 5$ & 7.65 \\
\hline アルニコ系 & $\mathrm{Al}-\mathrm{Ni}-\mathrm{Co}_{0}$ 系 $\quad(\mathrm{Al}+\mathrm{Ni}+\mathrm{Co}+\mathrm{Cu}+\mathrm{Fe})$ & $50 \sim 80$ & 7. 30 \\
\hline
\end{tabular}

$ろ^{1)}$ 。

\section{2 バインダー}

バインダーは, 成形加工機の種類と応用製品の要求特性 に合わせて選定される。ボンド磁石用バインダーは, 高充 填性が要求されるため, 全ての樹脂が使用できるわけでは ない。パインダーは, 磁粉を高充填でき，しかも充填後の 機械的強度や流動性, 而熱老化性, 而溶剤性, 耐水性, 而 薬品性などに優れたものでなければならない。現在使用さ れているバインダーを表 2 に示す。また，特性については 後述する「バインダーの特性と分散」の項で述べる。

\section{3 ボンド磁石の成形加工方法}

ボンド磁石は，バインダーに磁粉を高充填した磁性コン
パウンドを成形加工して得られる。その加工方法は，プラ スチックを成形加工する全ての方法で行われている。表 2 に成形加工方法, バインダー, 磁粉の種類及び充填量を示 す。充填量は, 射出成形用コンパウンドで 50〜 70 Vol.\%, エポキシ樹脂を使用する圧縮成形では，80９０ Vol.\%む 充填している。このように成形加工ができる極限まで磁粉 を高充填する理由は, 磁気特性が充填量の容量に大略比例 するからである。

\section{4 射出成形機によるボンド磁石の成形方法}

成形加工方法の一例として, 射出成形機によるボンド磁 石の製造工程を図 1 に示す ${ }^{2)}$ 。磁気特性の高いボンド磁石 を得るには, 磁粉, 磁性コンパウンド, 金型, 成形加工技 術，脱磁・着磁技術などが優れていなければならない。ま

表 2 ボンド磁石の成形加工方法とバインダー及び磁石粉末材料

\begin{tabular}{|c|c|c|c|}
\hline 成形加工方法 & バインダー(樹脂) & 磁石粉末 (磁粉) & $\begin{array}{l}\text { 磁 粉 } \\
\text { 充填量 }\end{array}$ \\
\hline 射出成形 & $\begin{array}{l}\text { 6PA, 12PA, PA6T } \\
\text { PPS, EVA, EEA, 他 }\end{array}$ & $\begin{array}{l}\text { フェライト }(\mathrm{Ba}, \mathrm{Sr}) 、 \mathrm{Sm}-\mathrm{Co} \text { 系 } \\
\mathrm{Nd}-\mathrm{Fe}-\mathrm{B} \text { 系、Sm-Fe-N, Al-Ni-Co 系 }\end{array}$ & $50 \sim 70$ \\
\hline 押出成形 & $\begin{array}{l}\text { PVC 系、CPE 系、EEA 系 } \\
\text { 12PA，NBR，杖师对系 }\end{array}$ & $\begin{array}{l}\text { フェライト }(\mathrm{Ba}, \mathrm{Sr}), \mathrm{Nd}-\mathrm{Fe}-\mathrm{B} \text { 系 } \\
\mathrm{Sm}-\mathrm{Fe}-\mathrm{N} \text { 系 }\end{array}$ & $50 \sim 70$ \\
\hline $\begin{array}{l}\text { 圧延成形 } \\
\text { (カレンダ-成形) }\end{array}$ & $\begin{array}{l}\text { PVC 系、CPE 系、EPM, EPD } \\
\text { NBR, クロロプレン、他 }\end{array}$ & $\begin{array}{l}\text { フェライト }(\mathrm{Ba}, \mathrm{Sr} / \text { 板状 }) \\
\mathrm{Nd}-\mathrm{Fe}-\mathrm{B} \text { 系 }\end{array}$ & $50 \sim 70$ \\
\hline 圧縮成形 & エポキシ樹脂 (EP) & $\begin{array}{l}\mathrm{Nd}-\mathrm{Fe}-\mathrm{B} \text { 系、Sm-Co 系 } \\
\mathrm{Sm}-\mathrm{Fe}-\mathrm{N} \text { 系 }\end{array}$ & $80 \sim 90$ \\
\hline
\end{tabular}

（磁粉充填量：Vol.\%)

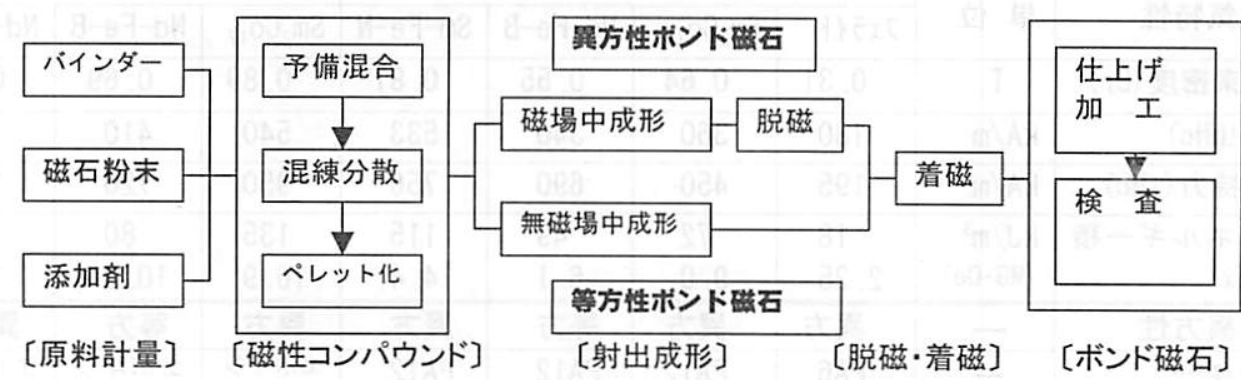

図 1 射出成形ボンド磁石の製造工程図 


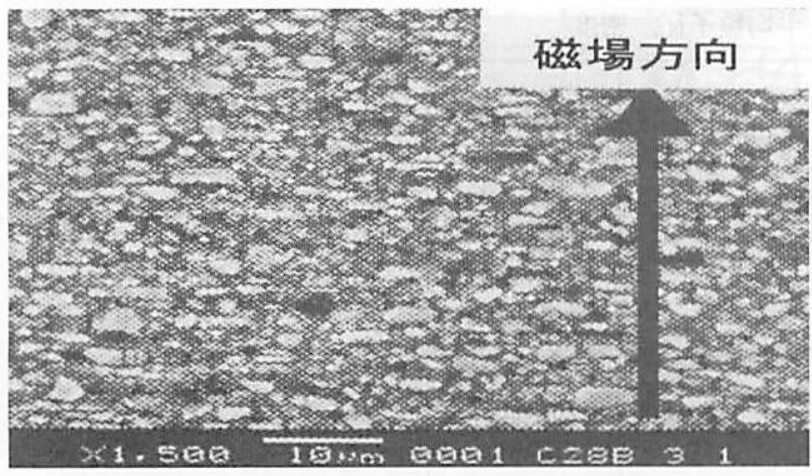

図 2 ボンド磁石の磁場配向 SEM 写真

た，ボンド磁石には，磁粉結晶の $\mathrm{C}$ 軸がランダムな方向 を向いている等方性ボンド磁石と C 軸が一定方向を向い ている異方性ボンド磁石がある。異方性ボンド磁石は，磁 場射出成形機を使用し金型キャビティ内に磁場を形成し, そこに溶融した磁性コンパウンドを射出し磁粉を配向させ る。配向した磁粉は, 磁力線が走る方向を向いたまま樹脂 の固化によって固定される。異方性磁石の磁気特性は, C 軸方向に強い磁力を発現する。図 2 にフェライトボンド磁 石の磁粉が配向している状態を示す3)。配向磁場の強さは, フェライト系で $10 \mathrm{kOe}(800 \mathrm{kA} / \mathrm{m})$ 以上, 希土類系で $13 \mathrm{kOe}(1040 \mathrm{kA} / \mathrm{m})$ 以上の磁場発生装置が望ましい。 配向磁場が十分でないと配向度が低く，磁気特性む低くな る。

\section{5 ボンド磁石の磁気特性}

ボンド磁石の磁気特性は, 磁粉の種類, 成形加工方法, 異方性・等方性によって大きく異なる。表 3 にボンド磁石 の磁気特性例を示す ${ }^{4)}$ 。この中の最大エネルギー積 (BH) $\max$. は, 単位体積当たりの磁石から取り出せる最大磁束 量の目安を示す值である。值が大きいほど磁力が強い磁石 と言う。

\section{3. ボンド磁石の磁粉の分散}

ボンド磁石に使用する磁性コンパウンドは, 磁粉, バイ ンダー, 添加剤などがよく分散し, 均質な複合体を形成し
ている必要がある。分散が良いコンパウンドは, 成形され たボンド磁石の機械的強度が高く, 溶融時の流動性もよく なる。流動性が高いと, 磁粉の配向度が上がり磁力の高い ボンド磁石になる。すなわち分散は，ボンド磁石の成形加 工性や機械的強度, 磁気特性などの性能を引き出す重要な 手段である。

一方, 磁粉を分散させる際の難易度については, それ程 難度の高いものではない。磁粉の平均粒子経は, 表 1 に示 すようにカーボンナノチューブや有機顔料のような $100 \mathrm{~nm}$ 以下のナノ粒子でないため, 混練時に二次凝集体が多量に 発生するようなことは少ない。しかしながらボンド磁石は, 磁力を高めるため磁粉を極限まで高充填しており，容量的 に少ないバインダーを一つ一つの粒子表面に均一に行き渡 らせるところに困難さがあり，混練・分散技術が必要にな る。

分散に関わる主な要因は, 磁粉の粉体特性, バインダー の特性, 磁粉の表面処理と添加剤, 適正な混練装置などで ある。以下これらの要因と分散について述べる。

\section{1 磁粉の粉体特性と分散}

機械粉砕で得られる磁粉の粒子群は, 径や形状が不均一 な粒子で構成されている。図 2 はフェライトの例を示す。 粉体物性は，最終製品に大きな影響を与えることから，粉 体特性を把握することは分散にとっても大变重要である。 ボンド磁石で多用される粉体特性は, 平均粒子径, 粒子形 状, 真密度, 嵩密度, 圧縮密度, 比表面積, 吸油量, 粒度 分布などである。ボンド磁石に使用されている各種磁粉の 平均粒子径は，1〜100 $\mu \mathrm{m}$ に含まれており，比較的大き いため, 混練時に二次凝集が多発することは少ない。その ため取扱いも比較的容易ではあるが, 高充填性が要求され ているためボンド磁石の分散には, 平均粒子径, 粒子形状, 圧縮密度などの粉体特性の把握が特に重要である。

\section{2 パインダーの特性と分散}

高充填された磁粉が高分散状態にあるときのバインダー は, 磁粉粒子一つ一つの表面を薄い樹脂膜で包み込んでい

表 3 各種ボンド磁石の磁気特性例

\begin{tabular}{|c|c|c|c|c|c|c|c|c|}
\hline \multirow[b]{2}{*}{ 磁気特性 } & \multirow[b]{2}{*}{ 単 位 } & \multicolumn{4}{|c|}{ 射出成形 } & \multicolumn{3}{|c|}{ 圧縮成形 } \\
\hline & & フェライト & $\mathrm{Sm}_{2} \mathrm{Co}_{17}$ & $\mathrm{Nd}-\mathrm{Fe}-\mathrm{B}$ & $\mathrm{Sm}-\mathrm{Fe}-\mathrm{N}$ & $\mathrm{Sm}_{2} \mathrm{Co}_{17}$ & $\mathrm{Nd}-\mathrm{Fe}-\mathrm{B}$ & $\mathrm{Nd}-\mathrm{Fe}-\mathrm{B}$ \\
\hline 残留磁束密度 (Br) & $T$ & 0.31 & 0.64 & 0.55 & 0.81 & 0.89 & 0.69 & 0.98 \\
\hline 保持力 (bHc) & $\mathrm{kA} / \mathrm{m}$ & 180 & 360 & 340 & 533 & 540 & 410 & - \\
\hline 固有保持力 (iHc) & $\mathrm{kA} / \mathrm{m}$ & 195 & 450 & 690 & 756 & 950 & 720 & 1034 \\
\hline $\begin{array}{l}\text { 最大エネルギ一積 } \\
\text { (BH) max. }\end{array}$ & $\begin{array}{l}\mathrm{kJ} / \mathrm{m}^{3} \\
(\mathrm{MG} \cdot 0 \mathrm{e})\end{array}$ & $\begin{array}{r}18 \\
2.25 \\
\end{array}$ & $\begin{array}{r}72 \\
9.0\end{array}$ & $\begin{array}{r}49 \\
6.1 \\
\end{array}$ & $\begin{array}{r}115 \\
14.4 \\
\end{array}$ & $\begin{array}{r}135 \\
16.9 \\
\end{array}$ & $\begin{array}{r}80 \\
10.0 \\
\end{array}$ & $\begin{array}{r}159 \\
19.9 \\
\end{array}$ \\
\hline 等方・異方性 & - & 異方 & 異方 & 等方 & 異方 & 異方 & 等方 & 異方 \\
\hline バインダー & - & PA6 & PA12 & PA12 & PA12 & エポキシ & エポキシ & エポキシ \\
\hline
\end{tabular}


る状態とも言える。また，磁粉の高充填性と高い機械的強 度を得るには, 薄く強い樹脂膜であると同時に, 磁粉表面 とバインダーの親和性の高いむのが要求される。現在多用 されているバインダーの特性を分類すると次のようになる。

(1)溶融粘度が低く結晶性樹脂：PA6，PA12，PPSなど。 (2)極性を有し，他のポリマーや可塑剤と相溶する樹脂：

EVA, EEA, PVC, CPEなど。

(3)架橋によって耐熱性, 耐油性, 機械的強度に優れる樹 脂：NBR， EPDM，クロロプレンゴム。

(4)エポキシ基を有し，金属磁粉との密着性が強く硬化時 に収縮が少ない樹脂：エポキシ樹脂。

\section{3 磁粉の表面処理剤・添加剤と分散}

表面処理剤や添加剤は，磁粉表面の濡れ性を高め分散を 良くすることと, 磁性コンパウンドの流動性を高める重要 な働きをする。表面処理剤としては, 主にシランカップリ ング剤が使用される。特にポリアミド樹脂にフェライトを 高充填する場合は，アミノシランで表面処理しないと流動 性, 機械的強度, 磁気特性, 成形品の外観など全く悪く製 品にならない。シランカップリング剂の表面処理で重要な ことは, 適正な添加量を添加することと, 処理剤がフェラ イト表面とポリアミド官能基がしっかり反応するようにす ることである。例として, 平均粒子径 : $1.26 \mu \mathrm{m}$, 比表面 積 : $1.76 \mathrm{~m}^{2} / \mathrm{g}$ のストロンチウムフェライトにアミノシラ ン $\mathrm{H}_{2} \mathrm{NC}_{3} \mathrm{H}_{6} \mathrm{Si}\left(\mathrm{OC}_{2} \mathrm{H} 5\right)_{3}$ を約 $0.5 \%$ 添加し, PA6 に 90 重 量\%混練・分散させたものが磁性コンパウンドである5

金属間化合物の希土類磁粉とエポキシ樹脂の場合は，エ ポキシ基と金属系磁粉との密着性が高いためフェライトほ ど表面処理効果が顕著ではない。しかし，エポキシシラン を使用することによって, 樹脂との密着性がより高くなり, 界面から進入する水分を抑え，防錆効果む得られるという 報告もある。

添加凧としては，脂肪酸系界面活性剤などがよく使われ 分散の改良の他, コンパウンドの流動性改良, 離型性を高 める目的で添加されることあある。

\section{4 混練装置と分散}

磁性コンパウンドの混練装置は, バインダーの種類によっ て異なる。ポリアミド樹脂や PPS の場合は, 二軸押出機 が多用されている。磁粉を高充填するためその分散には, スクリューの形状や長さ (L/D) が重要になり, さらに磁 粉濃度のバラッキを防止するために原料供給方法にも工夫 がされている。押出成形や圧延成形に使用するフレキシブ ルな磁性コンパウンドは, 加圧ニーダーで混練・分散した 後, それぞれの成形加工機に供給されることが多い。圧縮 成形用のエポキシ系希土類コンパウンドの混練には, 高速 混合機す使用されている。いずれの混練機も高分散之品質 の安定化を図るため, 各社それぞれのノウハウをむって, 製造条件を定めている。

\section{4. 磁石のエネルギー分野への応用}

磁石がエネルギー分野に応用される際, 大きく二つに分 けることが出来る。一つは省エネルギー, 高効率, 軽量化 などエネルギーを節約する分野であり，もう一つは，発電 機でエネルギーを生む分野である。

\section{1 希土類系ボンド磁石と焼結磁石の応用}

表 4 に示すように磁石は, モータや発電機に多用されて いるが，現状では殆どがモー夕分野である。ボンド磁石は, モータの小型化, 軽量化, 高効率化, 省エネ化などェネル ギーに関連する応用分野に欠かせない部品として重要な役 割を果たしている。特にハードデスクドライブ (HDD), 光デスクドライブ (ODD) の駆動機構には, 小型で瞬発力 と持久力の双方が要求されるため, 磁力が高いネオジム系 ボンド磁石やネオジム系燒結磁石が多量に使用されている。

モー夕の巻線を永久磁石に替えると，電力消費を伴わな い磁束発生という機能によって, 効率が $1 \sim 5 \%$ 程度向上 すると言われている ${ }^{6)}$ 。また磁力が高いほど効率を高くす ることができる。例えば日本中のモータの効率が $1 \%$ 向上 すると 50 億 $\mathrm{kWh}$ の省エネになり原発 1.5 基分の電力消 費を抑えることが出来ると試算されている6

今や小型モー夕以外の大型モー夕分野でもネオジム系焼

表 4 希土類ボンド磁石と焼結磁石の応用分野

\begin{tabular}{|c|c|c|}
\hline 応用分野 & 希土類ボンド磁石 ${ }^{(a)}$ & 希土類焼結磁石 ${ }^{(b)}$ \\
\hline 自動車用モータ・発電機 & 23 wt. \% & 37 wt. \% \\
\hline HDD・ODD/ボ イスコ价E-夕 & 37 & 34 \\
\hline MR I /核磁気共鳴画像法 & 0 & 11 \\
\hline 民生・家電用品、F A & 17 & 15 \\
\hline 事務機器 & 15 & 0 \\
\hline その他 & 8 & 3 \\
\hline 合 & 100 & 100 \\
\hline
\end{tabular}

出典：(a) MQI 西津正晃/2011BM シンポジウム

（b）藤森信彦 第 14 回磁気応用シンポジゥム 2006 年 
結磁石が応用されている。永久磁石式同期モー夕(PMSM) は，永久磁石の磁界を用いて駆動力を発生させるモータで ある。磁力の高いネオジム磁石により, 高効率で小型化が 可能なモータとして幅広い分野で利用されている。例えば, 自動車関連の HV・EV に応用され，走行距離を $35 \mathrm{~km} /$ '炎 $^{\circ}$ まで伸ばしている。また，エアコンコンプレッサー，エレ ベータ, 電車などの駆動モータに使われ, 消費電力削減に 大きく寄与している。

\section{2 洋上風力発電への応用}

有力な再生可能エネルギーとして注目されている風力発 電機にも希土類燒結磁石が期待されている。風力発電は, 世界的にみると日本は出遅れているが, 買電価格が固定さ れるFIT 制度によって風力発電事業が有望と見なされて いる。日本近海の洋上風力発電の賦存量は膨大であると推 計されていることああって, 風力発電関連各社は, 洋上風 車の技術確立や量産体制の構築を急いでいる。

発電機には, 卷線式と永久磁石式がある。それぞれ一長 一短はあるが, 近年は多極磁石式の発電機によって増速機 を省略した「ギアレス方式」が注目されるようになってき た。永久磁石式は, 重量・体積あたりの発電力が高い, 発 電機の効率がよい，構造が簡単でメンテナンスが容易であ るなど優れた特長を有している。現在未だ少ないが，今後 のネオジム磁石の伸びを期待したい。

\section{5.おわりに}

ボンド磁石の磁粉は, 有機顔料やカーボンブラック, カー ボンナノチューブのように微細なナノ粒子でなく，比較的 大きいため, 混練時に二次凝集による固い分散不良は起り にくい。その一方でボンド磁石は, 磁粉の容量がバインダー より多いため, 少ないバインダー量を磁粉粒子一個一個の表 面に行き渡らせるところに難しさと混練・分散技術が必要 になる。その分散技術には, バインダーの選択, 圧縮密度
が高く磁気特性に優れた磁粉, 表面処理剤の選定と処理技 術, 混練装置の選定と混練条件の最適化などが重要になる。

一方磁石のエネルギー分野への応用では, 電力消費量を 節約する分野と電力を生む分野で応用されている。日本国 内の総消費電力に占めるモー夕の割合は，51\%で高い割合 を示している ${ }^{6)}$ 。のような背景からモー夕に使用する電 力の節約が, 低炭素社会実現の重要課題であると言える。 永久磁石式同期モー夕 (PMSM) は, 巻線式の誘導モ一夕・ 電磁石同期モー夕などより効率的であるため, 磁石方式に 替える余地は十分にある。

次世代の自動車や省エネ家電などの基盤技術を支えるも のの一つが, 強い磁力を発現する永久磁石であるとも言え る。磁力の強い希土類磁石は, いま資源問題に直面してい るが, 産官学による新技術の開発, 中国以外の国の希土類 鉱石の採掘開始, リサイクルシステムの構築など, 着々と 進展している。

四方海に囲まれた日本の洋上風力発電む漸く注目されて きた。発電機に希土類永久磁石を使用することによって, 小型でハイパワーな発電機を得ることができる。関連する 周辺技術の開発や電力多元化を実現する発送電管理体制の 構築など課題も多いが, 今後希土類磁石の大きな市場とし て期待して良いと思う。

\section{参 考 文 献}

1）佐川眞人, 浜野正昭, 平林眞編, “永久磁石”，アグネ技術 センター, 288 (2007).

2）芳賀美次，成形加工， 15，795（2003）.

3）佐川黃人, 浜野正昭, 平林眞編, “永久磁石”，アグネ技術 センター, 212 (2007).

4）芳賀美次，“混練・分散の基礎と先端的応用技術”，テクノ システム, 360 (2003).

5）芳賀美次，“混練・分散の基礎と先端的応用技術”，テクノ システム, 359 (2003).

6）日経エレクトロニクス 2010 年 9 月 20 号, No. 1039, 39 (2010). 